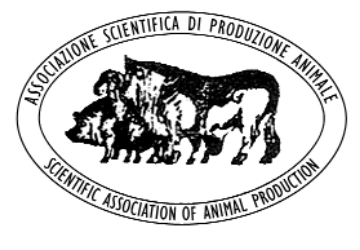

\title{
The relative absorption of fatty acids in brown trout (Salmo trutta) fed a commercial extruded pellet coated with different lipid sources
}

\author{
Giovanni Mario Turchini ${ }^{1}$, Tiziana Mentasti ${ }^{2}$, Fabio Caprino ${ }^{2}$, \\ Ivan Giani², Sara Panseri², Federica Bellagamba², \\ Vittorio Maria Moretti², Franco Valfré ${ }^{2}$
}

\author{
${ }^{1}$ School of Ecology and Environment. Deakin University, Australia. \\ 2 Dipartimento di Scienze e Tecnologie Veterinarie per la Sicurezza Alimentare. \\ Università di Milano, Italy.
}

Corresponding author: Prof. Vittorio Maria Moretti. Dipartimento di Scienze e Tecnologie Veterinarie per la Sicurezza Alimentare. Università di Milano. Via Trentacoste 2, 20134 Milano, Italy - Tel. +39 0250315760 Fax: +390250315746 - Email: vittorio.moretti@unimi.it

Paper received January 27, 2005; accepted April 8, 2005

\begin{abstract}
The objective of the present study was to investigate the fatty acid absorption capabilities of brown trout (Salmo trutta) fed commercial extruded diets. Five commercial extruded pellets, different only in the lipid sources used for fat coating, were tested on juvenile brown trout for 45 days. The trout were reared in fresh water at $14.6 \pm 0.4^{\circ} \mathrm{C}$ and $7.7 \pm$ $0.3 \mathrm{mg} / \mathrm{l}$, temperature and dissolved oxygen, respectively. The tested lipid sources were fish oil, canola oil, oleine oil, swine fat and poultry fat. After the adaptation period faeces were collected by gently stripping from anaesthetized fish. Fatty acid analysis was performed on experimental diets and on collected faeces to evaluate the relative absorption capabilities of the trout digestive system with respect to each detected fatty acid. The use of the relative absorption efficiency ( $\mathrm{rAE}$ ) was opted to evaluate the intrinsic capability of each fatty acid to be absorbed. Brown trout showed a specific preferential order of absorption of the fatty acids, preferring shorter over longer chain fatty acids and preferring the more unsaturated to the more saturated fatty acids. The fatty acid that showed the best relative absorbability was the $\mathrm{C} 18: 4 \mathrm{n}-3(\mathrm{rAE}=5.14 \pm 0.72)$, which has a fairly short carbon chain, but at the same time a high unsaturation level, followed by the $\mathrm{C} 18: 3 n-3(\mathrm{rAE}=3.38 \pm 0.30)$. The fatty acid that showed the worst relative absorbability $(\mathrm{rAE}=0.21 \pm 0.02)$ was $\mathrm{C} 24: 1 \mathrm{n}-9$.
\end{abstract}

Key Words: Brown trout, Dietary fatty acid, Relative absorption efficiency

RIASSUNTO
ASSORBIMENTO DEGLI ACIDI GRASSI NELLA TROTA FARIO (SALMO TRUTTA) ALIMENTATA
CON DIFFERENTI DIETE COMMERCIALI

Allo scopo di studiare l'assorbimento degli acidi grassi in esemplari di trota fario (Salmo trutta) cinque diete commerciaIi, differenti solamente in base alla fonte lipidica utilizzata per la grassatura finale, sono state somministrate ad animali allevati in acqua dolce (a temperatura di $14,6 \pm 0,4^{\circ} \mathrm{C}$ ed ossigeno disciolto pari a 7,7 $\pm 0,3 \mathrm{mg} / \mathrm{l}$ ) per un periodo di tempo di 45 giorni. Le fonti lipidiche utilizzate nella sperimentazione sono state l'olio di pesce, l'olio di colza, le oleine vegetali, il grasso suino e il grasso da sottoprodotti avicoli. Dopo il periodo di adattamento alla dieta si è proceduto al campionamento di materiale fecale attraverso un'accurata operazione di strippaggio su esemplari anestetizzati. Si è proceduto quindi all'analisi della composizione in acidi grassi, sia delle diete sperimentali sia dei campioni di feci raccolti, al 
fine di stimare l'efficienza di assorbimento nel tratto gastrointestinale delle trote di ciascun acido grasso. A questo scopo nel presente studio è stato utilizzato l'indice di efficienza di assorbimento relativo ( $A A E$ ) per valutare la capacità intrinseca di ciascun acido grasso di essere assorbito. La trota fario ha mostrato possedere un ordine preferenziale di assorbimento degli acidi grassi, preferendo gli acidi grassi corti rispetto a quelli a catena più lunga e preferendo quelli più insaturi rispetto a quelli più saturi. L'acido grasso che è stato assorbito maggiormente è stato il C18:4n-3 (rAE = 5,14 \pm 0,72 ), che è caratterizzato da una catena carboniosa non eccessivamente lunga ma allo stesso tempo da un alto grado di insaturazione, seguito in ordine dal C18:3n-3 ( $r A E=3,38 \pm 0,30)$. L'acido grasso che è stato assorbito relativamente di meno è stato invece il C24:1n-9 ( $r A E=0,21 \pm 0,02)$.

Parole chiave: Trota fario, Acidi grassi della dieta, Assorbimento relativo

\section{Introduction}

Concerns about an overexploitation of marine resources for fish oil production have been widely expressed (Bell, 1998; De Silva, 1999; Naylor et al., 2000; De Silva, 2001), therefore the issue of fish oil replacement for aquafeeds has recently been studied (Green and Selivonchick, 1990; Craig and Gatlin, 1995; Guillou et al., 1995; Torstensen et al., 2000; Turchini et al., 2000; Gunasekera et al., 2002). To deal with fish oil replacement, the knowledge of the digestibility of lipids, and in particular fatty acids, seems absolutely necessary.

The limited studies on lipid digestibility in finfish have indicated that lipid digestibility is affected by water temperature and fish size, as well as by the level of the dietary components, by the adaptation time to the diet and by the dietary lipid sources (Austreng et al., 1980; Appleford and Anderson, 1997; Ishikawa et al., 1997; Olsen et al., 1998; Hertrampf and Piedad-Pascual, 2000; Gunasekera et al., 2002). Investigations into lipids in fish diets and faeces reveal a preferential order of absorption of the fatty acids (Sigurgisladottir et al., 1992; Koven et al., 1994), demonstrating that the digestive lipases may have a higher activity towards certain fatty acids (Gunasekera et al., 2002) and also that fish absorb fatty acids selectively during digestion of the diet (Johnsen et al., 2000).

Almost all the previous studies were carried out on different fish species with the use of different markers to assay the apparent digestibility of the fatty acids. Johnsen et al. (2000) proposed the use of multivariate statistics for evaluation of the relative absorption of fatty acids without using external markers. The lack of uniformity in the approach had confused the comprehension of the real capability of one specific fatty acid to be absorbed by a specific fish species. The aim of the present study is to investigate the fatty acid absorption capabilities of brown trout (Salmo trut$t a)$ fed commercial extruded diets without the use of an added external marker.

The rationale for using brown trout is that it represents a high-value species for recreational and commercial purposes, as well as for high quality cuisine as an alternative to rainbow trout (Oncorhynchus mykiss). A great future within aquaculture is foreseen for this species (Snow et al., 2001; Youngson et al., 2003). The European production in the last few years has increased considerably from 5800 tons per year in 1999 to more than 10,400 tons in 2002 (FAO, 2004). Furthermore, the key nutrient requirements of brown trout are well known (Arzel et al., 1992; 1994; 1995; 1998; Koskela et al., 1997; Pirhonen and Forsman, 1998; Regost et al., 2001).

\section{Material and methods}

\section{Animals and rearing conditions}

Juvenile brown trout spawned and reared in captivity ("Stabilimento Giudicariese di Pescicoltura s.r.l.", Trento, Italy) were transported to the experimental facilities located in the "SalmoPan s.r.l." hatchery (Cremona, Italy). Fish were reared in $1200 \mathrm{l}$ fibreglass square tanks supplied with bore water and the flow rate was set to $12 \mathrm{l} / \mathrm{min}$ for all tanks throughout the experiment.

Temperature and dissolved oxygen were measured daily and they were, respectively, $14.6 \pm 0.4^{\circ} \mathrm{C}$ and $7.7 \pm 0.3 \mathrm{mg} / \mathrm{l}$ (mean $\pm \mathrm{SD}$ ). The natural photoperiod was expanded in the early morning and in the afternoon and set at 10:14-h light/dark cycle.

\section{Experimental diets}

A commercial closed formula extruded pellet was supplied from "A.S.A. Agridea s.r.l." (Verona, 
Italy). This non-oil coated pellet ( analysed for the proximate composition (moisture 5.2\%; protein $51.6 \%$; total lipid $10.8 \%$; ash $8.8 \%$ ) and then coated with five different lipid sources to obtain five isonitrogenous and isolipidic (respectively $47 \%$ protein and $20 \%$ total lipid as fed) diets. Twenty kilograms of pellets were coated with 2.3 $\mathrm{kg}$ of oil. The lipid sources tested in the experiment were fish oil (FO), canola oil (CO), poultry fat (PF), swine fat (SF) and oleine oil (OO). Roughly the alternative lipid sources tested represented $50 \%$ of the total fat of the diets; the remaining $50 \%$ was from fish oil added during the extrusion process. Oleine oil was a technical rendered by-product oil of a mix of vegetal and animal oil which was separated by fractionation.

\section{Experimental design and sampling}

The experiment was carried on 1275 fish randomly distributed in 15 tanks; therefore each tank was stocked with 85 fish. At the beginning a random sample of 15 fish was removed and weighed to the nearest $0.01 \mathrm{~g}$. The initial weight was $58.37 \pm$ $0.68 \mathrm{~g}$ (mean $\pm \mathrm{SD}$ ). All juveniles used in the trial were of the same size and in good health condition.

Every experimental diet was assigned randomly to three different tanks. Fish were fed twice a day (at 9:00 $\mathrm{h}$ and 17:00 h) to apparent satiation for 45 days and feed consumption was recorded weekly. At the end of 45 days, a period long enough to avoid the effect on the digestion of dietary compounds (Appleford and Anderson, 1997), faeces were gently stripped in the early morning from 85 anaesthetized fish of each tank in accordance with Austreng (1978) and pooled. Not all the fish gave a satisfactory amount of faeces. The total amount of faeces collected from each tank was approximately $5.0 \mathrm{~g}$ (approximately $0.1 \mathrm{~g}$ for each fish). Pooled faeces samples were kept frozen at $-80^{\circ} \mathrm{C}$ until analysis.

Fish were wiped dry before stripping to avoid the contamination of faeces with surface mucus (Jobling, 1994) and special care was used to avoid having undigested feed and incidental seminal liquids included in the stripped samples (Austreng, 1978; Jobling, 1994). Stripping was carried out only one time on each animal, deleting the possible effect of handling stress and the repeated use of anaesthetics, which may affect peristalsis in the intestine (Storebakken et al., 1998).

\section{Chemical analysis}

Experimental diets were analysed for moisture, protein, lipid and ash using standard methods (AOAC, 1996). The proximate composition of the diets (Table 1) was such that these were isonitrogenous and isolipidic.

Fatty acids analysis was performed on three sub-samples of each experimental diet and on pooled faeces samples for each experimental tank. The extraction of total lipids was performed according to Bligh and Dyer (1959). The preparation of fatty acid methyl esters was performed according to Christie (1982). Fatty acids analysis was carried out on a Perkin Elmer gas-chromatograph (Model 8700) fitted with an automatic sampler (Model AS 2000B) and a FID detector. The conditions used were the following: Omegawax fused silica capillary column (30 m x 0.25 mm I.D.) (Supelco Inc., Bellafonte, PA); temperature programmed from 100 to $250^{\circ} \mathrm{C}$ at 3 ${ }^{\circ} \mathrm{C} / \mathrm{min}$., held for $10 \mathrm{~min}$. Carrier gas was helium at $1.0 \mathrm{ml} / \mathrm{min}$., inlet pressure $12 \mathrm{psi}$.

The fatty acid analysis of the diets (Table 1) showed some important differences in single fatty acid values. $\mathrm{OO}$ diet showed the presence of lauric acid (C12:0), and its amount was $16.59 \%$ of the total of measured fatty acids. Of the saturated fatty acids in the diets palmitic acid (C16:0) was the highest, varying from $12.38 \%$ to $23.64 \%$, respectively, for $\mathrm{CO}$ and $\mathrm{SF}$ diets. Oleic acid (C18:1n-9) was higher in the CO diet $(41.28 \%)$ compared the other diets. FO diet showed the higher level of eicosapentaenoic acid (EPA, C20:5n-3) and docosahexaenoic acid (DHA, C22:6n-3), $8.85 \%$ and $10.89 \%$, respectively.

\section{Statistical analysis}

Data are reported as mean values \pm standard error (s.e.). Homogeneity of variance was confirmed and comparison between means was by one-way ANOVA. Student-Newman-Keuls was used as post hoc test for comparison of the means among different dietary treatments. Significance was accepted at probabilities of 0.05 or less. Statistical analyses were performed by SPSS 10.1 (SPSS Inc., Chicago, Illinois). Linear regressions were performed using the method of minimization of the sum-of-squares of the vertical distances of the points from the line, forcing the line to go through the origin $(0,0)$ by Graph Pad Prism 3.0 (Graph Pad Software Inc., San Diego, California). 
Table $1 . \quad$ Fatty acids (weight $\%$ ) and proximate composition of the experimental diets.

\begin{tabular}{|c|c|c|c|c|c|}
\hline & \multicolumn{5}{|c|}{ Diets } \\
\hline & FO & $\mathrm{CO}$ & 00 & PF & SF \\
\hline $\mathrm{C} 12: 0$ & 0.15 & 0.07 & 16.59 & 0.13 & 0.15 \\
\hline $\mathrm{C} 14: 0$ & 6.64 & 2.63 & 9.29 & 3.39 & 3.54 \\
\hline $\mathrm{C} 16: 0$ & 21.91 & 12.38 & 19.38 & 22.09 & 23.64 \\
\hline C18:0 & 4.75 & 3.35 & 5.93 & 6.13 & 9.48 \\
\hline $\mathrm{C} 16: 1$ & 6.61 & 2.56 & 2.84 & 5.13 & 3.76 \\
\hline C18:1n-9 & 16.60 & 41.28 & 18.93 & 27.88 & 28.97 \\
\hline C18:1n-7 & 2.72 & 2.90 & 1.90 & 2.59 & 2.77 \\
\hline C20:1n-9 & 2.42 & 1.57 & 1.06 & 1.12 & 1.34 \\
\hline$C 22: 1 n-11$ & 2.89 & 0.97 & 1.00 & 0.98 & 1.04 \\
\hline C24:1n-9 & 0.72 & 0.39 & 0.32 & 0.34 & 0.41 \\
\hline$C 18: 2 n-6$ & 5.00 & 14.29 & 6.66 & 14.18 & 10.30 \\
\hline C18:3n-6 & 0.16 & 0.01 & 0.06 & 0.09 & 0.06 \\
\hline C18:3n-3 & 1.49 & 5.50 & 0.86 & 1.53 & 1.10 \\
\hline$C 18: 4 n-3$ & 2.12 & 0.81 & 0.83 & 0.96 & 0.87 \\
\hline$C 20: 2 n-6$ & 0.23 & 0.14 & 0.20 & 0.24 & 0.39 \\
\hline$C 20: 3 n-6$ & 0.14 & 0.01 & 0.06 & 0.10 & 0.19 \\
\hline$C 20: 4 n-6$ & 0.84 & 0.30 & 0.21 & 0.58 & 0.47 \\
\hline$C 20: 5 n-3$ & 8.85 & 3.45 & 3.48 & 3.84 & 3.58 \\
\hline$C 22: 5 n-3$ & 1.37 & 0.45 & 0.48 & 0.56 & 0.54 \\
\hline$C 22: 6 n-3$ & 10.89 & 4.48 & 4.60 & 5.41 & 4.84 \\
\hline \multicolumn{6}{|c|}{ Proximate composition ( $\%$ as fed): } \\
\hline Moisture & 4.7 & 4.4 & 4.7 & 4.3 & 4.2 \\
\hline Protein & 46.3 & 46.4 & 46.6 & 46.7 & 46.6 \\
\hline Lipid & 19.7 & 19.9 & 19.6 & 19.5 & 19.5 \\
\hline Ash & 7.8 & 7.8 & 7.7 & 7.8 & 7.8 \\
\hline
\end{tabular}

FO: Fish Oil; CO: Canola Oil; OO: Oleine Oil; PF: Poultry Fat; SF: Swine Fat.

Calculation of the relative absorption efficiency (rAE) of fatty acids

Assuming that for an assumption of a specific fatty acid equal to zero (assuming the supply from intestinal bacterium or endogenous cells was negligible) the respective amount in the faeces should also be zero, it was decided to force the line through the origin. The lines that best fit the trends are described by the following equations where $\mathrm{X}$ is the percent of the fatty acid in the diet and $\mathrm{Y}$ is the percent of the fatty acid in the faeces (Figure 1 and Figure 2):

$$
\begin{array}{lll}
\text { C14:0 } & \mathrm{Y}=1.0061 \mathrm{X} & \left(\mathrm{R}^{2}=0.58 ; \mathrm{P}<0.0001\right) \\
\mathrm{C} 16: 0 & \mathrm{Y}=1.7994 \mathrm{X} & \left(\mathrm{R}^{2}=0.53 ; \mathrm{P}<0.0001\right) \\
\text { C18:0 } & \mathrm{Y}=2.9731 \mathrm{X} & \left(\mathrm{R}^{2}=0.74 ; \mathrm{P}<0.0001\right) \\
\text { C18:1n-9 } & \mathrm{Y}=0.4238 \mathrm{X} & \left(\mathrm{R}^{2}=0.94 ; \mathrm{P}<0.0001\right) \\
\text { C18:2n-6 } & \mathrm{Y}=0.3229 \mathrm{X} & \left(\mathrm{R}^{2}=0.61 ; \mathrm{P}<0.0001\right) \\
\text { C18:3n-3 } & \mathrm{Y}=0.2336 \mathrm{X} & \left(\mathrm{R}^{2}=0.78 ; \mathrm{P}<0.0001\right)
\end{array}
$$

The slope, and mathematically the linear coefficient, indicates the trend of potential absorption of the fatty acid. If a slight increase in the dietary level of a specific fatty acid corre- 
sponds a larger increase in the percentage of the same fatty acid in the faeces, this may indicate that the fatty acid is not well absorbed by the fish intestine. Therefore it seems possible to assert that the higher the slope the lower the absorption. Thus, considering that the slope of the line has an inverse correlation to the absorption of the fatty acid, it was possible to propose that the inverse ratio (1/slope) could represent a coefficient able to describe the relative absorption efficiency of the fatty acids. The relative absorption efficiency ( $\mathrm{rAE}$ ) was, therefore, described by the following equation:

$$
\mathrm{rAE}=\frac{\% \text { fatty acid in diet }}{\% \text { fatty acid in faeces }}
$$

Using this coefficient, which is considerable as a modification to the absorption efficiency index proposed by Jobling (1994), it is possible to quantify and then compare the relative absorption efficiency of each fatty acid.

\section{Results}

In Table 2 fatty acids composition of the faeces is reported. The fatty acids found in highest amounts in faeces, irrespective of the dietary treatment, were palmitic acid (C16:0), stearic acid (C18:0), oleic acid (C18:1n-9) and DHA (C22:6n-3). Palmitic acid varied from $27.36 \pm 1.42 \%$ to $40.63 \pm$ $0.23 \%$ for faeces of fish fed $\mathrm{CO}$ and $\mathrm{PF}$, respectively, while the highest level of stearic acid was found in faeces of fish fed SF diet $(25.83 \pm 2.51 \%)$ and the lowest $(13.90 \pm 0.88 \%)$ for faeces of fish fed $\mathrm{CO}$ diet. Oleic acid and DHA varied from a minimum of $7.26 \pm 0.27 \%$ and $6.62 \pm 1.46 \%$ for faeces of fish fed FO and SF, respectively, to a maximum of $17.76 \pm 2.17 \%$ and $10.81 \pm 1.49 \%$ for faeces of fish fed CO diet.

The relationships of the amount of C14:0, C16:0, C18:0, C18:1n-9, C18:2n-6 and C18:3n-3 measured in diet and faeces are summarised in Figure 1 and Figure 2. In Table 3 and Figure 3 the average relative absorption efficiency (rAE) for each fatty acid is reported. The fatty acid that

Figure 1. The relationships between dietary saturated fatty acids (C14:0, C16:0 and $\mathrm{C} 18: 0)$ and their amount in the faeces. Vertical bars represent the standard error of the mean.

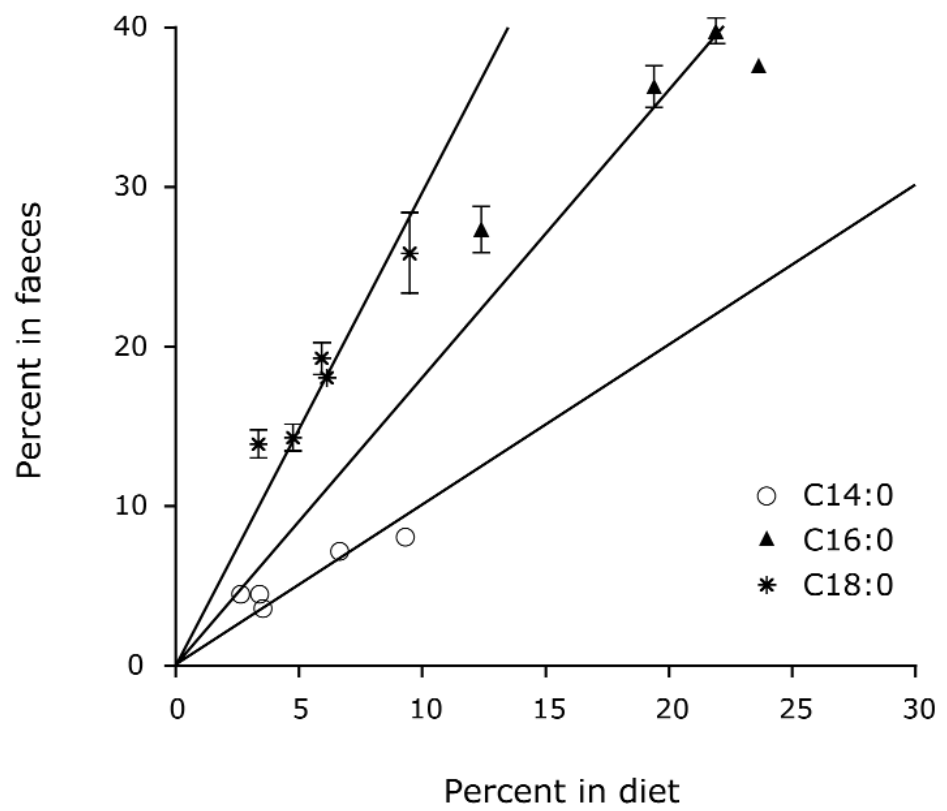


Figure 2. The relationships between dietary C18:0, C18:1n-9, C18:2n-6 and C18:3n-3 and their amount in the faeces. Vertical bars represent the standard error of the mean.

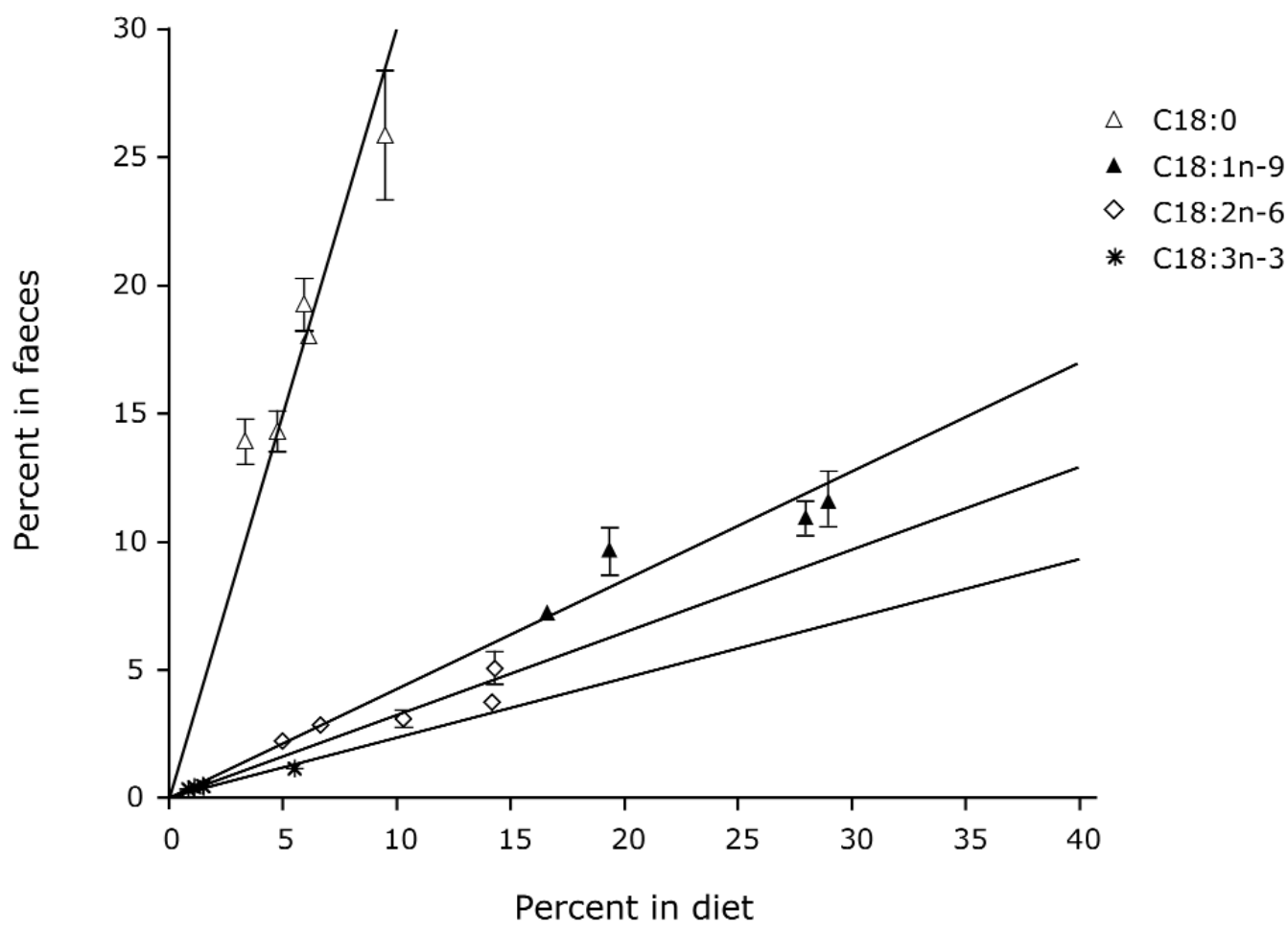

showed the best relative absorbability was the C18:4n-3 (5.14 \pm 0.72$)$, which has a fairly short carbon chain but at the same time a high unsaturation level, followed by the C18:3n-3 (3.38 \pm 0.30$)$ and EPA (3.37 \pm 0.32$)$. The fatty acids that showed the worst relative absorbability were $\mathrm{C} 24: 1 \mathrm{n}-9$ and C18:0 (0.21 \pm 0.02 and $0.32 \pm 0.01$, respectively).

With respect to the dietary treatment, some differences were found among the average relative absorption efficiency of the diets and among the relative absorption efficiency of fatty acids (Table 3). FO diet showed the higher absorbability of fatty acids, while $\mathrm{CO}$ diet showed the worst absorbability $(2.02 \pm 0.07$ vs $1.33 \pm 0.08$, respectively) $(\mathrm{P}<0.05)$. No significant differences were found among the average relative absorbability of $\mathrm{OO}, \mathrm{PF}$ and SF diets. The monounsaturated fatty acids C18:1n-9 and C22:1n-11 were absorbed in equal amounts for all the five experimental diets, but a significant effect was shown on absorption of some saturated and polyunsaturated fatty acids. In fact, $\mathrm{C} 12: 0, \mathrm{C} 14: 0$ and $\mathrm{C} 16: 0$ were worst absorbed in animals fed $\mathrm{CO} \operatorname{diet}(\mathrm{P}<0.05)$, while C12:0 and C16:0 were best absorbed in fish fed $\mathrm{OO}$ and $\mathrm{SF}$ diets, respectively.

At the same time the relative absorption efficiency of n- 6 and n-3 polyunsaturated fatty acids was also significantly affected by the dietary treatment. The C18:2n-6 showed the worst relative absorption efficiency in fish fed $\mathrm{FO}$ and $\mathrm{OO}$ diets; the C18:3n- 6 showed the worst relative absorption efficiency in fish fed CO diet. The C20:3n- 6 was the best absorbed fatty acid in fish fed FO diet, if compared with fish fed the other experimental diets. All the n-3 polyunsaturated fatty acids (except for C18:3n-3 and C18:4n-3) were statistically more absorbed in fish fed diets prepared with 
Table 2. Fatty acids composition of faeces (weight \%).

Dietary treatments

\begin{tabular}{lccccc}
\hline & FO & CO & OO & PF & SF \\
\hline C12:0 & $0.07^{\mathrm{a}} \pm 0.03$ & $0.03^{\mathrm{a}} \pm 0.03$ & $2.87^{\mathrm{b}} \pm 0.39$ & $0.06^{\mathrm{a}} \pm 0.03$ & $0.02^{\mathrm{a}} \pm 0.02$ \\
$\mathrm{C} 14: 0$ & $7.18^{\mathrm{b}} \pm 0.33$ & $4.47^{\mathrm{a}} \pm 0.23$ & $8.07^{\mathrm{b}} \pm 0.45$ & $4.48^{\mathrm{a}} \pm 0.17$ & $3.61^{\mathrm{a}} \pm 0.33$ \\
$\mathrm{C} 16: 0$ & $39.74^{\mathrm{b}} \pm 0.71$ & $27.36^{\mathrm{a}} \pm 1.42$ & $36.30^{\mathrm{b}} \pm 1.24$ & $40.63^{\mathrm{b}} \pm 0.23$ & $37.58^{\mathrm{b}} \pm 1.82$ \\
$\mathrm{C} 18: 0$ & $14.30^{\mathrm{a}} \pm 0.80$ & $13.90^{\mathrm{a}} \pm 0.88$ & $19.25^{\mathrm{a}} \pm 1.00$ & $18.05^{\mathrm{a}} \pm 0.11$ & $25.83^{\mathrm{b}} \pm 2.51$ \\
$\mathrm{C} 16: 1$ & $1.94^{\mathrm{b}} \pm 0.13$ & $1.42^{\mathrm{b}} \pm 0.07$ & $1.24^{\mathrm{b}} \pm 0.14$ & $1.64^{\mathrm{ab}} \pm 0.03$ & $1.21^{\mathrm{b}} \pm 0.20$ \\
$\mathrm{C} 18: 1 \mathrm{n}-9$ & $7.26^{\mathrm{a}} \pm 0.27$ & $17.76^{\mathrm{b}} \pm 2.17$ & $9.51^{\mathrm{a}} \pm 0.60$ & $11.00^{\mathrm{a}} \pm 0.53$ & $11.59^{\mathrm{a}} \pm 1.03$ \\
$\mathrm{C} 18: 1 \mathrm{n}-7$ & $2.06 \pm 0.21$ & $2.07 \pm 0.11$ & $1.60 \pm 0.14$ & $1.76 \pm 0.05$ & $1.71 \pm 0.14$ \\
$\mathrm{C} 20: 1 \mathrm{n}-9$ & $1.26^{\mathrm{b}} \pm 0.11$ & $1.38^{\mathrm{b}} \pm 0.10$ & $0.76^{\mathrm{a}} \pm 0.07$ & $0.79^{\mathrm{a}} \pm 0.03$ & $0.82^{\mathrm{a}} \pm 0.11$ \\
$\mathrm{C} 22: 1 \mathrm{n}-11$ & $2.36 \pm 0.53$ & $2.39 \pm 0.79$ & $0.54 \pm 0.32$ & $0.62 \pm 0.35$ & $0.39 \pm 0.20$ \\
$\mathrm{C} 24: 1 \mathrm{n}-9$ & $2.52^{\mathrm{ab}} \pm 0.11$ & $3.02^{\mathrm{b}} \pm 0.42$ & $1.98^{\mathrm{ab}} \pm 0.21$ & $1.96^{\mathrm{ab}} \pm 0.05$ & $1.52^{\mathrm{a}} \pm 0.28$ \\
$\mathrm{C} 18: 2 \mathrm{n}-6$ & $2.21^{\mathrm{a}} \pm 0.07$ & $5.08^{\mathrm{c}} \pm 0.64$ & $2.87^{\mathrm{ab}} \pm 0.11$ & $3.74^{\mathrm{a}} \pm 0.15$ & $3.09^{\mathrm{b}} \pm 0.35$ \\
$\mathrm{C} 18: 3 \mathrm{n}-6$ & $0.28^{\mathrm{b}} \pm 0.02$ & $0.06^{\mathrm{a}} \pm 0.06$ & $0.16^{\mathrm{ab}} \pm 0.01$ & $0.13^{\mathrm{a}} \pm 0.06$ & $0.05^{\mathrm{b}} \pm 0.05$ \\
$\mathrm{C} 18: 3 \mathrm{n}-3$ & $0.48^{\mathrm{a}} \pm 0.09$ & $1.16^{\mathrm{b}} \pm 0.17$ & $0.35^{\mathrm{a}} \pm 0.06$ & $0.46^{\mathrm{a}} \pm 0.06$ & $0.43^{\mathrm{a}} \pm 0.06$ \\
$\mathrm{C} 18: 4 \mathrm{n}-3$ & $0.27 \pm 0.01$ & $0.08 \pm 0.08$ & $0.28 \pm 0.04$ & $0.16 \pm 0.09$ & $0.05 \pm 0.05$ \\
$\mathrm{C} 20: 2 \mathrm{n}-6$ & $0.24^{\mathrm{a}} \pm 0.02$ & $0.48^{\mathrm{b}} \pm 0.05$ & $0.31^{\mathrm{ab}} \pm 0.05$ & $0.30^{\mathrm{ab}} \pm 0.02$ & $0.35^{\mathrm{ab}} \pm 0.08$ \\
$\mathrm{C} 20: 3 \mathrm{n}-6$ & $0.07^{\mathrm{a}} \pm 0.03$ & $0.42^{\mathrm{b}} \pm 0.10$ & $0.30^{\mathrm{ab}} \pm 0.06$ & $0.30^{\mathrm{ab}} \pm 0.05$ & $0.26^{\mathrm{ab}} \pm 0.07$ \\
$\mathrm{C} 20: 4 \mathrm{n}-6$ & $0.85 \pm 0.16$ & $0.97 \pm 0.10$ & $0.80 \pm 0.18$ & $0.81 \pm 0.02$ & $0.62^{2} \pm 0.13$ \\
$\mathrm{C} 20: 5 \mathrm{n}-3$ & $2.19 \pm 0.68$ & $1.53 \pm 0.14$ & $1.05 \pm 0.09$ & $1.22 \pm 0.21$ & $1.16 \pm 0.07$ \\
$\mathrm{C} 22: 5 \mathrm{n}-3$ & $0.31 \pm 0.17$ & $0.51 \pm 0.11$ & $0.31 \pm 0.02$ & $0.37 \pm 0.07$ & $0.3 \pm 0.05$ \\
$\mathrm{C} 22: 6 \mathrm{n}-3$ & $9.27 \pm 0.84$ & $10.81 \pm 1.49$ & $8.50 \pm 1.74$ & $7.51 \pm 0.55$ & $6.62^{2} \pm 1.46$ \\
\hline
\end{tabular}

In any row, values without superscript or with the same superscript are not significantly $(P>0.05)$ different from each other.

fish oil as a lipid source.

\section{Discussion}

The feeding regime was to satiation and no statistically significant differences were observed among dietary treatments (varying from 45 to 53 grams of feed for each fish during the entire experiment), demonstrating that there was no effect of the lipid source on the diet palatability for brown trout.

The faecal fatty acid composition for all the tested lipid sources was widely different from that of the diets as reported for shortfin eels (Anguilla australia) fed with animal and vegetal oil diets by Gunasekera et al. (2002), while Johnsen et al. (2000) did not report this variation in faeces from
Atlantic salmon (Salmo salar) fed diets with different marine lipid sources.

The linear regression, comparing the percentage of fatty acid in the diet and in the faeces, made it possible to evaluate the trend of relative absorption of the single fatty acid. It was in this way evident how the brown trout, for the same level of saturation, has a specific preferential order of absorption, preferring shorter chain fatty acids to longer chain fatty acids (Figure 1) and, for the same length of chain, preferring the more unsaturated to the more saturated fatty acids (Figure 2). The same preferential order was demonstrated in previous studies on different species and by using different methodologies (Austreng et al., 1980; 
Figure 3. The relative absorption efficiency ( $\mathrm{rAE}$ ) for each fatty acid detected in the diet and in the faeces.

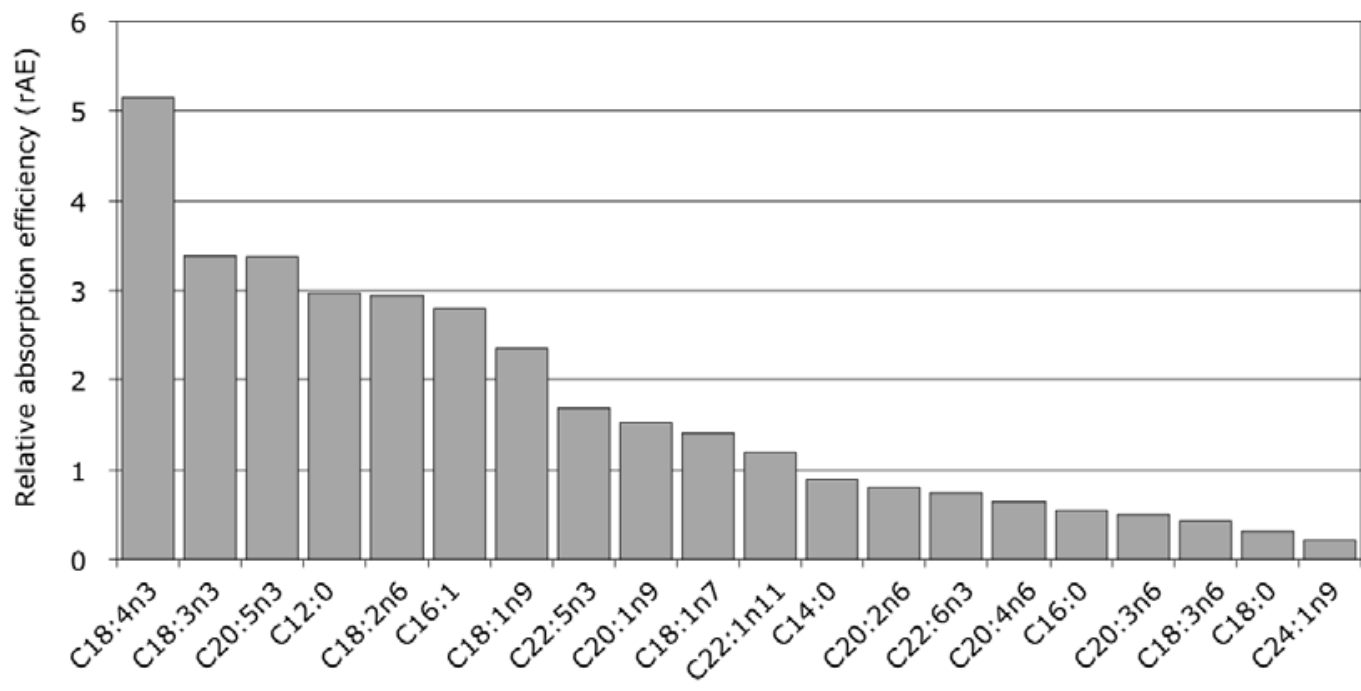

Sigurgisladottir et al., 1992; Olsen et al., 1998).

The relative absorption efficiency represents an answer to the need to possess an efficient tool of analysis to compare the relative variation in diet and faeces of all the detected fatty acids. This index assembles the demonstrated effect of both chain length and saturation level of fatty acid on specific absorption capability. Only two fatty acids showed a higher value of $\mathrm{rAE}$ with respect to eicosapentaenoic acid, which was previously considered one of the most absorbable and digestible (Austreng et al., 1980; Appleford and Anderson, 1997; Ishikawa et al., 1997; Olsen et al., 1998; Johnsen et al., 2000; Torstensen et al., 2000).

The variation of the value of the $\mathrm{rAE}$ of almost all the fatty acids is in agreement with previous works that used different methods of evaluation of the absorbability of the fatty acids. Gunasekera et al. (2002), using chromic oxide as an external marker, showed the best apparent digestibility for C18:4n-3, followed by C18:3n-3 and EPA, in shortfin eel. Torstensen et al. (2000) on Atlantic salmon, using yttrium oxide as external marker, revealed an apparent digestibility for C14:0, C16:0 and C18:0 with the same order revealed in this study and C18:3n-3 and EPA digestibility as two of the highest. Other studies showed similar responses (Sigurgisladottir et al., 1992; Johnsen et al, 2000). All this information confirms the trustworthiness of the proposed method and show that fatty acid absorbability in brown trout is similar to that in other finfish species.

An effect on the capability of fatty acid relative absorbability relative to the position of the first double bond from the distal end is remarkable. C18:3n- 6 showed a very low value of $\mathrm{rAE}(0.43 \pm$ 0.05 ), while C18:3n-3 was one of the highest, and except for $18: 2 \mathrm{n}-6(\mathrm{rAE}=2.94 \pm 0.18)$, all the other $\mathrm{n}-6$ fatty acids had a very low $\mathrm{rAE}$ (while almost all n-3 fatty acids showed a very good relative absorbability index).

Species-specific differences in fatty acid absorbability could be pointed out by the observation that polyunsaturated fatty acids (PUFA) of the n-6 series were higher in the faeces with respect to the diet. Similarly Torstensen et al. (2000) found a low apparent digestibility for PUFA $n-6$ in Atlantic salmon, while PUFA n-6 were not even detected in Artic charr (Salvelinus alpinus) and on shortfin eel faeces by Olsen et al. (1998) and Gunasekera et al. (2002) respectively, showing a complete relative 
Table 3. The relative absorption efficiency ( $\mathrm{TAE}$ ) for different fatty acids in relationship to different dietary treatments. Data represent mean \pm SE of mean.

\begin{tabular}{|c|c|c|c|c|c|c|}
\hline \multicolumn{7}{|c|}{ Dietary treatments } \\
\hline & $\mathrm{CO}$ & FO & 00 & $\mathrm{PF}$ & SF & Means* \\
\hline $\mathrm{C} 12: 0$ & $0.75^{a} \pm 0.01$ & $1.54^{b} \pm 0.20$ & $6.00^{\wedge} \pm 0.78$ & $1.48^{b} \pm 0.25$ & $2.00^{b} \pm 0.01$ & $2.98^{\mathrm{ef}} \pm 0.80$ \\
\hline $\mathrm{C} 14: 0$ & $0.59^{\mathrm{a}} \pm 0.03$ & $0.93^{b c} \pm 0.04$ & $1.16^{d} \pm 0.06$ & $0.76^{b} \pm 0.03$ & $1.00^{\mathrm{cd}} \pm 0.10$ & $0.89^{\mathrm{abcd}} \pm 0.06$ \\
\hline $\mathrm{C} 16: 0$ & $0.45^{\mathrm{a}} \pm 0.08$ & $0.55^{b} \pm 0.05$ & $0.54^{b} \pm 0.07$ & $0.54^{b} \pm 0.07$ & $0.63^{c} \pm 0.06$ & $0.54^{\mathrm{abc}} \pm 0.02$ \\
\hline $\mathrm{C} 18: 0$ & $0.24^{\mathrm{a}} \pm 0.07$ & $0.33^{b} \pm 0.07$ & $0.31^{\mathrm{ab}} \pm 0.06$ & $0.34^{b} \pm 0.05$ & $0.37^{b} \pm 0.04$ & $0.32^{\mathrm{a}} \pm 0.01$ \\
\hline $\mathrm{C} 16: 1$ & $1.81^{\mathrm{a}} \pm 0.10$ & $3.44^{b} \pm 0.22$ & $2.35^{b} \pm 0.23$ & $3.13^{b} \pm 0.06$ & $3.26^{b} \pm 0.46$ & $2.80^{\mathrm{ef}} \pm 0.19$ \\
\hline C18:1n9 & $2.39 \pm 0.28$ & $2.29 \pm 0.08$ & $2.01 \pm 0.14$ & $2.55 \pm 0.12$ & $2.54 \pm 0.22$ & $2.36^{e} \pm 0.09$ \\
\hline C18:1n7 & $1.41 \pm 0.07$ & $1.35 \pm 0.13$ & $1.20 \pm 0.11$ & $1.47 \pm 0.04$ & $1.64 \pm 0.13$ & $1.41^{\mathrm{bcd}} \pm 0.05$ \\
\hline $\mathrm{C} 20: 1 \mathrm{n} 9$ & $1.15^{\mathrm{a}} \pm 0.12$ & $1.95^{b} \pm 0.16$ & $1.43^{\mathrm{ab}} \pm 0.15$ & $1.41^{\mathrm{ab}} \pm 0.05$ & $1.68^{\mathrm{ab}} \pm 0.23$ & $1.52^{\mathrm{cd}} \pm 0.09$ \\
\hline C22:1n11 & $0.53 \pm 0.20$ & $1.33 \pm 0.25$ & $1.41 \pm 0.51$ & $1.19 \pm 0.38$ & $1.76 \pm 0.01$ & $1.19^{\mathrm{abcd}} \pm 0.16$ \\
\hline C24:1n9 & $0.13^{\mathrm{a}} \pm 0.02$ & $0.29^{b} \pm 0.01$ & $0.17^{\mathrm{a}} \pm 0.02$ & $0.18^{\mathrm{ab}} \pm 0.01$ & $0.29^{\mathrm{b}} \pm 0.06$ & $0.21^{\mathrm{a}} \pm 0.02$ \\
\hline $\mathrm{C} 18: 2 \mathrm{n} 6$ & $2.90^{\mathrm{b}} \pm 0.34$ & $2.27^{a} \pm 0.08$ & $2.33^{\mathrm{a}} \pm 0.09$ & $3.81^{\complement} \pm 0.15$ & $3.41^{b c} \pm 0.35$ & $2.94^{\mathrm{ef}} \pm 0.18$ \\
\hline $\mathrm{C} 18: 3 n 6$ & $0.06^{\mathrm{a}} \pm 0.01$ & $0.57^{b} \pm 0.04$ & $0.38^{b} \pm 0.01$ & $0.47^{b} \pm 0.01$ & $0.48^{\mathrm{b}} \pm 0.01$ & $0.43^{\mathrm{ab}} \pm 0.05$ \\
\hline $\mathrm{C} 18: 3 \mathrm{n} 3$ & $4.96 \pm 0.76$ & $3.27 \pm 0.52$ & $2.59 \pm 0.38$ & $3.45 \pm 0.47$ & $2.64 \pm 0.35$ & $3.38^{f} \pm 0.30$ \\
\hline $\mathrm{C} 18: 4 \mathrm{n} 3$ & $3.28^{\mathrm{a}} \pm 0.01$ & $7.87^{b} \pm 0.36$ & $3.10^{\mathrm{a}} \pm 0.41$ & $4.41^{\mathrm{a}} \pm 1.32$ & $6.40^{\mathrm{b}} \pm 0.01$ & $5.14^{9} \pm 0.72$ \\
\hline $\mathrm{C} 20: 2 \mathrm{n} 6$ & $0.31^{a} \pm 0.03$ & $0.98^{b} \pm 0.08$ & $0.67^{\mathrm{ab}} \pm 0.09$ & $0.81^{\mathrm{ab}} \pm 0.04$ & $1.24^{b} \pm 0.30$ & $0.80^{\mathrm{abcd}} \pm 0.10$ \\
\hline $\mathrm{C} 20: 3 \mathrm{n} 6$ & $0.20^{\mathrm{a}} \pm 0.01$ & $1.34^{\complement} \pm 0.01$ & $0.22^{\mathrm{a}} \pm 0.04$ & $0.36^{a} \pm 0.06$ & $0.85^{\circ} \pm 0.22$ & $0.50^{\mathrm{abc}} \pm 0.13$ \\
\hline $\mathrm{C} 20: 4 \mathrm{n} 6$ & $0.32^{\mathrm{a}} \pm 0.03$ & $1.06^{\mathrm{b}} \pm 0.17$ & $0.29^{\mathrm{a}} \pm 0.06$ & $0.72^{\mathrm{ab}} \pm 0.02$ & $0.83^{b} \pm 0.17$ & $0.64^{\mathrm{abc}} \pm 0.09$ \\
\hline$C 20: 5 n 3$ & $2.29^{\mathrm{a}} \pm 0.22$ & $4.77^{b} \pm 1.17$ & $3.36^{a} \pm 0.30$ & $3.35^{a} \pm 0.61$ & $3.12^{\mathrm{a}} \pm 0.18$ & $3.37^{f} \pm 0.32$ \\
\hline $\mathrm{C} 22: 5 \mathrm{n} 3$ & $0.99^{\mathrm{a}} \pm 0.26$ & $3.06^{b} \pm 0.65$ & $1.58^{\mathrm{a}} \pm 0.11$ & $1.59^{a} \pm 0.26$ & $1.68^{\mathrm{a}} \pm 0.26$ & $1.69^{\mathrm{d}} \pm 0.20$ \\
\hline $\mathrm{C} 22: 6 \mathrm{n} 3$ & $0.43^{\mathrm{a}} \pm 0.06$ & $1.19^{b} \pm 0.10$ & $0.58^{\mathrm{a}} \pm 0.11$ & $0.73^{a} \pm 0.06$ & $0.81^{\mathrm{a}} \pm 0.18$ & $0.75^{\mathrm{abcd}} \pm 0.08$ \\
\hline Means & $1.33^{\mathrm{a}} \pm 0.08$ & $2.02^{b} \pm 0.07$ & $1.59^{\mathrm{ab}} \pm 0.04$ & $1.61^{\mathrm{ab}} \pm 0.12$ & $1.69^{\mathrm{ab}} \pm 0.21$ & \\
\hline
\end{tabular}

In any row, values without superscript or with the same superscript are not significantly $(P>0.05)$ different from each other.

* In this column, values with the same superscript are not significantly $(P>0.05)$ different from each other.

absorption.

In brown trout a statistically different average relative absorbability of the different lipid sources and an effect of the lipid sources on the fatty acids absorption efficiency were recorded. On account of that which is reported above and discussed in this section, the highest average relative absorption of diet containing fish oil should not be a surprise. Fish oil, in fact, derives from industrial fisheries (e.g. capelin, herring, sand eel, mackerel, anchovy and sardine fisheries) (Sargent et al., 2002) and even if its chemical composition varies widely according to the single fish species, the fishing season, the geographical location and the processing techniques, the major characteristic of fish oil is the high level of unsaturated and above all of n-3 polyunsaturated fatty acids (Hertrampf and Piedad-Pascual, 2000). These are the fatty acids that showed the best relative absorption efficiency in brown trout when fish were fed a diet containing this lipid source. As fish oil is a valuable source of a great deal of essential (n-3) highly unsaturated 
and very digestible fatty acids, and because these fatty acids are a good source of energy, relatively large amounts of marine fish oils are used in feeds for trout, salmon and other cultured marine fishes, provided that they are carnivorous (Lovell, 1998).

Notwithstanding, it is clear that demand for fish oil from aquaculture will, before long, exceed supply. This problem will be exacerbated by climatic events such as El Niño, by growing environmental pressure to decrease exploitation pressure on finite marine resources, and by increasing consumer perception that levels of pollutants such as dioxin in fish oils have now reached unacceptable levels. For these reasons finding alternatives to fish oil in farmed fish feeds is becoming an increasingly urgent issue (Sargent et al., 2002).

On this subject, as regards its average relative absorption efficiency and therefore the digestibility of the lipid component, canola oil did not prove to be a good alternative lipid source as oil of marine origin. However canola oil, a rape-seed oil low in glucosinolates and erucic acid, having an adequate content of the essential linoleic acid, is considered a useful ingredient in diets for cultured aquatic animals, so much so that feeding low erucic acid rape-seed oil to Atlantic salmon (Salmo salar), juvenile Chinook salmon (Oncorhynchus tschawytscha), rainbow trout (Oncorhynchus mykiss), hybrid tilapia (Oreochromis mossambicus $\mathrm{x}$ Oreochromis aureus) and goldfish (Carassius auratus) did not negatively affect growth, feed conversion or survival rate (Hartfiel et al., 1981; Dosanjh et al., 1988; Higgs et al., 1989; Greene and Selivonchick, 1990; Wiegand, 1993).

\section{Conclusions}

By employing the relative absorption efficiency $(\mathrm{rAE})$ it was demonstrated that it is possible to evaluate the fatty acid absorption of a diet without the use of an external marker or complicated statistical calculations. This along with the possibility of obtaining a numeric measurement of the absorption and the possibility of using a commercial diet, make the $\mathrm{rAE}$ a promising tool for further investigations.

All the tested lipid sources seem usable for fat coating extruded pellets for brown trout, even if brown trout seems to prefer lipid from marine sources. In consideration of the high level of absorption recorded for the alpha-linolenic acid (C18:3n-3) with respect to the other fatty acids, the potential use of a source rich in C18:3n-3, such as linseed oil (Hertrampf and Piedad-Pascual, 2000), seems advisable.

The authors wish to thank Paolo Montesano for his helpful technical assistance.

This work was funded by a grant from the Ministry of Agricultural and Forestry Policies (MiPAF) Italy, Project 5C112, Fifth Plan of Fishery and Aquaculture.

\section{REFERENCES}

AOAC, 1996. Official Methods of Analysis of the Association of Official Analytical Chemists. AOAC, Arlington, USA.

Appleford, P., Anderson, T.A., 1997. Apparent digestibility of tuna oil for common carp, Cyprinus carpio - effect of inclusion level and adaptation time. Aquaculture. 148:143-151.

Arzel, J., Martinez Lopez, F.X., MÉtailler, R., StéPhan, G., Viau, M., Gandemer, G., Guillaume, J., 1994. Effect of dietary lipid on growth performance and body composition of brown trout (Salmo trutta) reared in seawater. Aquaculture. 123:361-375.

Arzel, J., Metailler, R., Huelvan, C., Faure, A., Guillaume, J., 1992. The specific nutritional requirements of brown trout (Salmo trutta). Búvísindi, Icelandic Agricultural Science. 6:77-92.

Arzel, J., Metailler, R., Kerleguer, C., Le Delliou, H., Guillaume, J., 1995. The protein requirement of brown trout (Salmo trutta) fry. Aquaculture. 130:67-78.

Arzel, J., Metailler, R., Le Gall, P., Guillaume, J., 1998. Relationship between ration size and dietary protein level varying at the expense of carbohydrate and lipid in triploid brown trout fry, Salmo trutta. Aquaculture. 162:259-268.

AustrenG, E., 1978. Digestibility determination in fish using chromic oxide marking and analysis of contents from different segments of the gastrointestinal tract. Aquaculture. 13:265-272.

Austreng, E., Skrede, A., Eldegard, Å., 1980. Digestibility of fat and fatty acids in rainbow trout and mink. Aquaculture. 19:93-95.

BELL, J.G., 1998. Current aspects of lipid nutriton in fish farming. In: K.D. Black and A.D. Pickering (eds.) Biology of farmed fish. Sheffield Academic Press, Sheffield, UK, pp 114-145. 
Bligh, E.G., Dryer, W.Y., 1959. A rapid method of total lipid extraction and purification. Can. J. Biochem. and Phys. 37:911-917.

Christie, W., 1982. Lipid analysis. Isolation, separation, identification and structural analysis of lipids. $2^{\text {nd }}$ edition, Pergamon Press, Oxford, UK.

Craig, S.R., Gatlin, D.M., 1995. Coconut oil and beef tallow, but not tricaprylin, can replace menhaden oil in the diet of red drum (Sciaenops ocellatus) without adversely affecting growth or fatty acid composition. J. Nutr. 125:3041-3048.

De Silva, S.S., 1999. Feed resources, usage and sustainability. In: N. Svennevig, H. Reinertsen and M. New (eds.) Sustainable aquaculture. Balkema, Rotterdam, The Netherlands, pp 221-242.

DE SiLVA, S.S., 2001. A global perspective of aquaculture in the new millennium. In: R.P. Subasinghe, P. Bueno, M.J. Phillips, C. Hough, S.E. McGladdery and J.R. Arthur (eds.) Aquaculture in the third millennium. NACA, Bangkok, Thailand and FAO, Roma, Italy, pp 431-459.

Dosanjh, B.S., Higgs, D.A., Plotnikoff, M.D., MARKert, J.R., DuCKLEY, J.T., 1988. Preliminary evaluation of canola oil, pork lard and marine lipid singly and in combination as supplemental dietary lipid sources for juvenile fall Chinook salmon (Oncorhynchus tschawytscha). Aquaculture. 68:325-343.

FAO, 2004. Fishstat Plus. Universal software for fishery statistical fine series.

GreEN, D.H.S., SELIVONCHICK, D.P., 1990. Effects of dietary vegetable, animal and marine lipids on muscle lipid and haematology of rainbow trout (Oncorhynchus mykiss). Aquaculture. 89:165-182.

Guillou, A., Soucy, P., Khalil, M., Abambounou, L., 1995. Effects of dietary vegetable and marine lipid on growth, muscle fatty acid composition and organoleptic quality of flesh of brook charr (Salvelinus fontinalis). Aquaculture. 136:351-362.

Gunasekera, R.M., Leelarasamee, K., De Silva, S.S., 2002. Lipid and fatty acid digestibility of three oil types in Australian shortfin eel, Anguilla australia. Aquaculture. 203:335-347.

Hartfiel, W., Schulz, D., Greuel, E., 1981. Investigations on the conversion of fats of the rainbow trout (Salmo gairdnerii). 2. The use of two different raw rape-oils in a synthetic food mixture. Fischwirt. 31:63-64.

Hertrampf, J.W., PIEDAd-PAscuAl, F., 2000. Handbook on ingredients for aquaculture feeds. Kluwer Academic Publishers, Dordrecht, The Netherlands.

Higgs, D.A., Dosanjh, B.S., Little, M., Roy, R.J.J., Mc BRIDE, J.R., 1989. Potential for including canola products (meal and oil) in diets for Oreochromis mossambicus x Oreochromis aureus. The current status of fish nutrition in aquaculture. pp 301-314 in Proc. $3^{\text {rd }}$ Int. Symp. Feeding and Nutrition in Fish, Toba, Japan.
Ishikawa, M., Teshima, S.I., Kanazawa, A., Koshio, S., 1997. Measurements of digestibilities of cholesterol and fatty acids using 5_-cholestane as an inert marker in the Nile tilapia, Oreochromis niloticus, and the freshwater prawn, Macrobrachium rosenbergii. J. Appl. Ichthyol. 13:31-35.

Jobling, M., 1994. Fish bioenergetics. Chapman \& Hall, London, UK.

Johnsen, R.I., Grahl-Nielsen, O., Roem, A., 2000. Relative absorption of fatty acids by Atlantic salmon Salmo salar from different diets, as evaluated by multivariate statistics. Aquacult. Nutr. 6:255-261.

Koskela, J., Pirhonen, J., Jobling, M., 1997. Variations in feed intake and growth of Baltic salmon and brown trout exposed to continuous light at constant low temperature. J. Fish Biol. 50:837-845.

Koven, W.M., Henderson, R.J., SARgent, J.R., 1994. Lipid digestion in turbot (Scophthalmus maximus). I. Lipid class and fatty acid composition of digesta from different segments of the digestive tract. Fish Physiol. Biochem. 13:69-79.

LOVELL, T., 1998. Nutrition and feeding of fish. Kluwer Academic Publishers, Norwell, USA.

NAYlor, R. L., GoldBurg, R.J., PRIMAVERA, J., KAUtSky, N., Beveridge, M. C. M., Clay, J., Folkes, C., Lubchence, J., Mooney, H., Troell, M., 2000. Effects of aquaculture on world food supplies. Nature. 405:1017-1024.

Olsen, R.E., Henderson, R.J., Ringø, E., 1998. The digestion and selective absorption of dietary fatty acids in Arctic charr, Salvelinus alpinus. Aquacult. Nutr. 4:13-21.

Pirhonen, J., Forsman, L., 1998. Effect of prolonged feed restriction on size variation, feed consumption, body composition, growth and smolting of brown trout, Salmo trutta. Aquaculture. 162:203-217.

Regost, C., Arzel, J., Cardinal, M., Laroche, M., KAUSHIK, S.J., 2001. Fat deposition and flesh quality in seawater reared, triploid brown trout (Salmo trutta) as affected by dietary fat levels and starvation. Aquaculture. 193:325-345.

SARgent, J.R., Tocher, D.R., BeLl, J.G., 2002. The lipids. In: J.E. Halver and R.W. Hardy (eds) Fish nutrition. Academic Press, San Diego, CA, USA, pp 181-257.

Sigurgisladottir, S., Lall, S.P., Parrish, C.C., ACKMAN, R.G., 1992. Cholestane as a digestibility marker in the absorption of polyunsaturated fatty acid ethyl esters in the Atlantic salmon. Lipids. 27:418-424.

Snow, M., RAYNARD, R.S., BRUnO, D.W., 2001. Comparative susceptibility of Arctic char (Salvelinus alpinus), rainbow trout (Oncorhynchus mykiss) and brown trout (Salmo trutta) to the Scottish isolate of infectious salmon anemia virus. Aquaculture. 196:47-54. 
Storebakken, T., Kvien, I.S., Shearer, K.D., GrisdaleHelland, B., Helland, S.J., Berge, G.M., 1998. The apparent digestibility of diets containing fish meal, soybean meal or bacterial meal fed to Atlantic salmon (Salmo salar): evaluation of different faecal collection methods. Aquaculture. 169:195-210.

Torstensen, B.E., Lie, Ø., Frøyland, L., 2000. Lipid metabolism and tissue composition in Atlantic Salmon (Salmo salar L.) - Effects of capelin oil, palm oil, and oleic acid-enriched sunflower oil as dietary lipid sources. Lipids. 35:653-664.

TurChini, G.M., MoRetTI, V.M., VAlfrè, F., 2000. Breve rassegna sulle fonti lipidiche alternative nei mangimi per l'acquacoltura. Riv. Ital. Acquacolt. 35:91-108.

WiEGAND, M.D., 1993. Study on the use of canola oil in the feed of larval goldfish (Carassius auratus L.). In: N. Nromage and R.J. Roberts (Eds.) Broodstock Management and Egg and Larval Quality, Blackwell Publishing Ltd, Oxford, UK, pp 220223.

Youngson, A.F., Jordan, W.C., Verspoor, E., Mc Ginnity, P., Cross, T., Ferguson, A., 2003. Management of salmonid fisheries in the British Isles: towards a practical approach based on population genetics. Fish. Res. 62:193-209. 